\title{
$1-1-20$ 複聴現象の検討
}

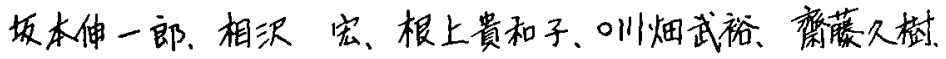

(弘前大)

\section{緒 言}

雨耳のピッ干感覚の差は、特以音に祄して敏感な人でなけれは気附かない事が多 い。我々は自崞才ージオイーターとスイープオッシレーターを連結する事いより、

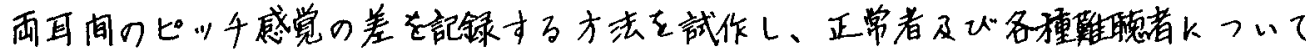

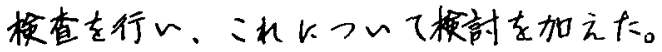

方法

自記才ージオメータ一の减衰調整軸飞スィープオッシレータ一の周没数变調軸と

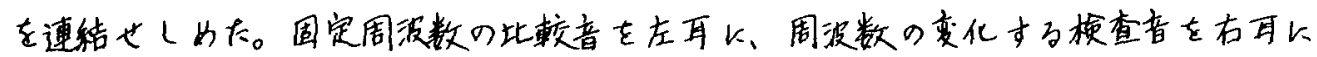

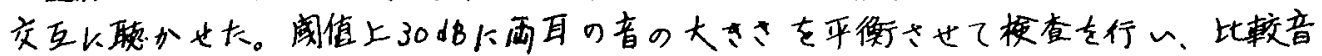

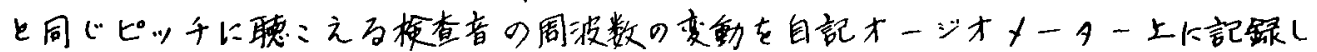
た。得られた服型の中点を平均し、:れを雨皌のピッ干差とした。 实㣏 (1)

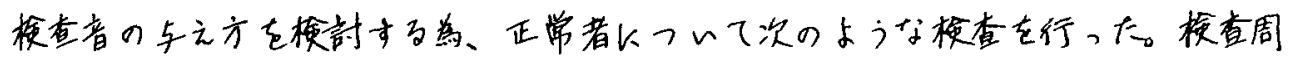

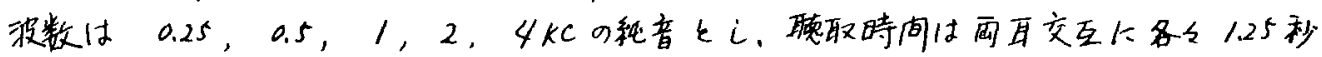
及び 0.5 秒の二棉七した。周波数变調速度は各周波数によ，て差があ万が、0.16

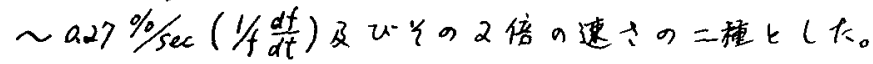

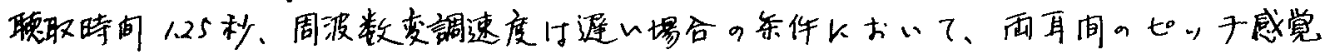

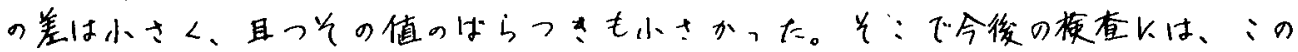

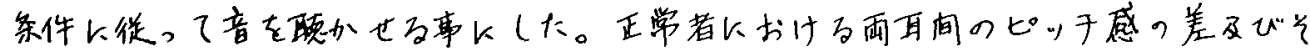
の值の祭集偏差古图/K示した。

实 验 (2)

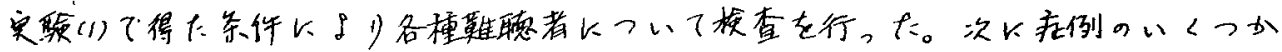
招介寸る。

\section{A）感音性蜼聴}

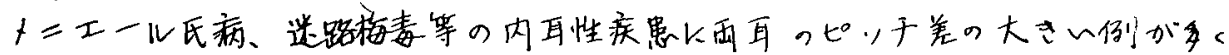

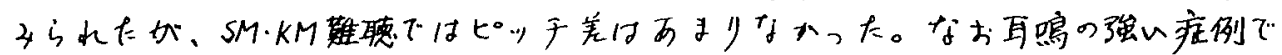

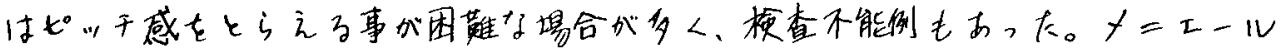

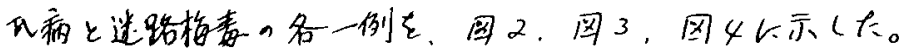

B）伝音性嚾㯖

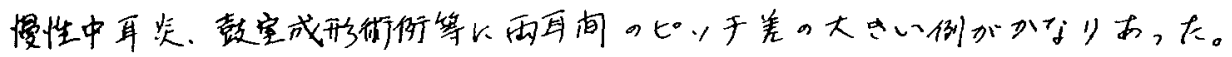

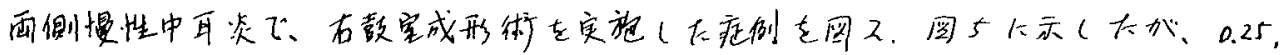

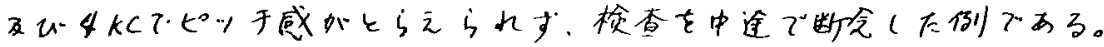

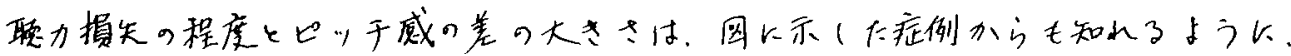
わまり相闺はなかった。 
143

結 語

我々は自記オージオメーターとス イープオッンレーターをを連結する 事以上小自記的以両耳间のピッ于 感觉の差を敦银する方法を考え、正 常者及v゙各種䧼㯖者下ついて梌查を 行的、气の症例の2.3を招介(た。 一般人音の大きさと高さとを得同す

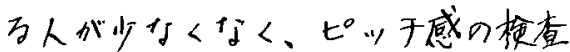
日比校的むずかしいとの印象を与之 た。

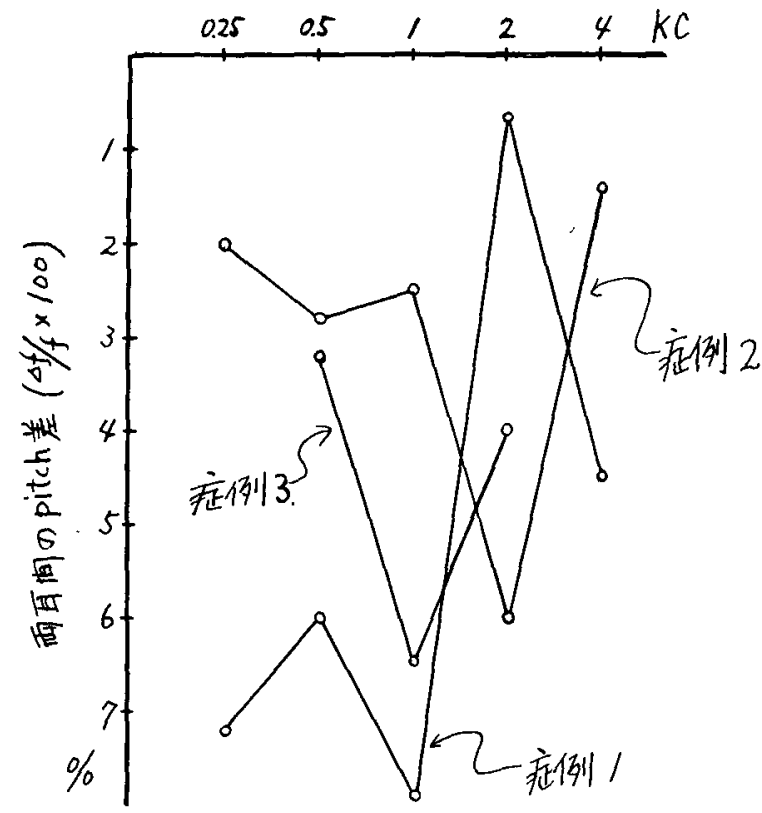

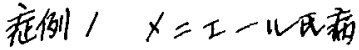
症列之，送路梅毒 症例了，画倒慢性中耳矢 右鼓空成形術例

四之各種蜼㯖例の雨㭻のpitch差

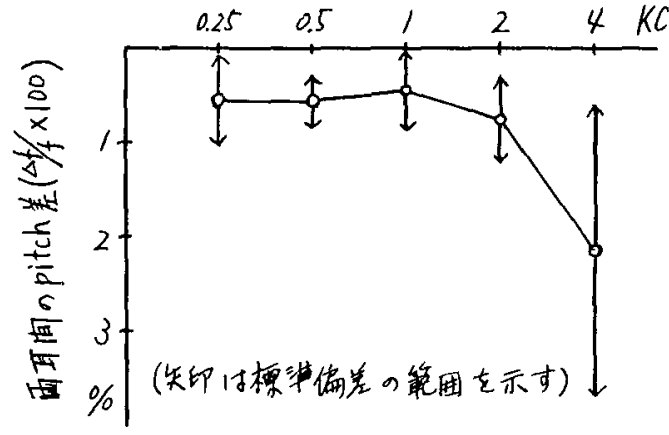

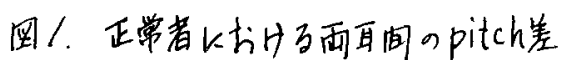

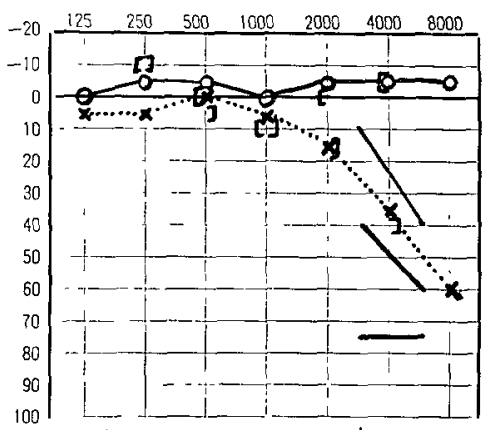

回了。症例/のオージオグラム

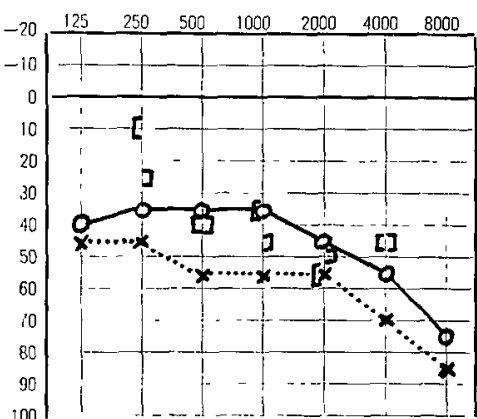

圆4症例2の才ーシオオ゙ラム

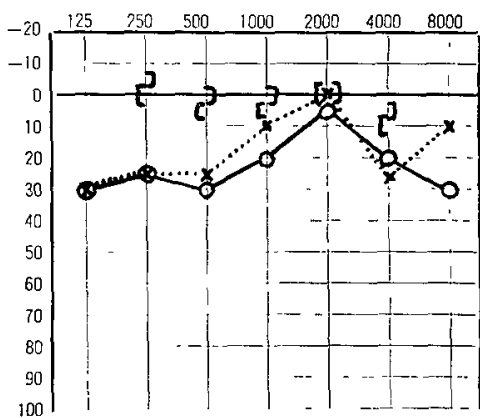

四5.疮例了のオージオイ゙ラム 